\title{
Plant Viruses Detection and Diagnosis Based on Polymerase Chain Reaction Techniques: Review
}

\author{
Bayissa Regassa \\ Ethiopia Institute of Agricultural Research, Ambo Agricultural Research Center, \\ P. O. Box 37, Ambo, Ethiopia
}

\begin{abstract}
Plant virus diseases result in the loss of billions of dollars annually by limiting plant production quantity and quality in the world. Among different strategies adapted for plant virus disease management, proper diagnosis and detection are the most important and essential strategies for the development of appropriate control measures. The current advanced techniques developed for the detection of plant viruses provided the chance to take practical managemental actions timely. Nowadays one of the most advanced diagnosis methods, polymerase chain reaction (PCR) is used extensively for the detection and identification of plant viruses. PCR is the advanced method that allows the specific amplification and hence detection of target DNA sequences from a mixture of nucleic acid extract in which specific amplification of targeted fragments of a single or a few copies of source DNA material is achieved within a few hours. The PCR method copies each piece of DNA fragments through all the cycles that leading to an exponential doubling of copies over time. Several modifications of PCR methods have been developed to boost the effectiveness of the method in diagnostic settings based on their applications. Reverse transcriptase PCR, immunocapture PCR, Multiplex PCR, co-operational PCR, and real-time PCR are the common and widely used types of PCR variants.
\end{abstract}

Keywords: Detection techniques; PCR; Plant virus

DOI: $10.7176 /$ ALST/86-02

Publication date:March $31^{\text {st }} 2021$

\section{INTRODUCTION}

Important agricultural crops are threatened by a wide range of plant viral diseases worldwide, resulting in losses of several billion dollars annually (Mumford et al., 2016). The greatest impact comes from viral infections with the rapid increase in the incidence of disease and local distribution. The main influences contributive to the emergence of the plant viruses are: (i) agricultural production systems based on mono production system with low genetic diversity and high plant diversity; (ii) the plant germplasm worldwide with plant pathogens, hosts, and vectors to new areas; (iii) climate change affecting the distribution area of the pathogen hosts and vectors; and (iv) biological ability to evolve and adapt quickly (Jones, 2009; Elena et al., 2014).

Proper identification and detection of plant viruses is the key significant step for its management method. Plant treatments after infection with the virus often do not result in effective control measures. Similarly, plant viral infections are best controlled by means of pre-infection control methods. The use of virus-free planting material is one of the most effective methods that farmers can use. The key elements in fruitful certification systems to produce virus-free propagation material is the accessibility of sensitive identification and detection methods (Makkouk and Kumari, 2006).

\section{PLANT VIRUS DETECTION and DIAGNOSIS}

The terms detection and diagnosis are used interchangeably. Detection is to find out the virus; while, diagnosis is the step that involves a vigilant investigation to determine the fundamental cause of the pathogen. Plant viruses are generally can be diagnosed and identified by using a various technique including symptom observation, particle morphology observation under an electron microscope, mechanical or vector transmission to indicator host plants, detection using virus-specific antibodies (serological assay) (Davis and Ruabete, 2010, Regassa et al., 2020). Symptom observations is a vital means for plant virus diagnosis in the field. However, this is not a convincing technique because with non-virus infected plants may exhibit virus-like symptoms which can be caused by unfavorable weather conditions, nutrient imbalances, infection by non-viral pathogens, insects, and the effect of herbicides (Agrios, 2005). Electron microscopy is the easiest way to detect viruses directly but is often not used for routine diagnostic purposes. Biological identification methods such as indicator plants, host range studies are helpful but it is a time-consuming process and require sophisticated glasshouse and continuing maintenance of the viruses for the test host. Serological techniques such as enzyme-linked immunosorbent assay is commonly used to detect and identify plant viruses where the titer of antibodies is high enough for the test (Sastry, 2013; Regassa et al., 2020, 2021). The development of nucleic acid (polymerase chain reaction) techniques transformed the detection and identification of plant viruses in plants (Sastry, 2013; Bhardwaj and Kulshrestha, 2020; Varma and Singh, 2020). 


\section{POLYMERASE CHAIN REACTION (PCR)}

PCR is a diagnostic technique initially established by Kary Mullis in 1985 (Mullis et al., 1986). The speed, sensitivity, specificity and versatility of PCR made it appropriate in many fields of study in biology (Hema and Konakalla, 2021) including detection of plant pathogens (Vincelli and Tisserat, 2008), molecular characterization (Alfaro-Fernandez et al., 2008), evolutionary studies (Roossinck, 2002), and DNA comparisons between related pathogen species (Kiss et al., 2008).

\subsubsection{Component of polymerase chain reaction}

To accomplish PCR, the following components are crucial.

DNA template: The template DNA may be in double-stranded or single form. Plant viruses whose nucleic-acid is RNA converted to cDNA before amplification.

Primers (forward and reverse): Primers comprise of short oligonucleotides that are indeed complementary to the sequence at the 3' end of each strand of the DNA to be amplified. Primers can be designed manually or by using software packages. The synthesize of primers are performed on an automated DNA synthesizer. While designing of primers care is required to get the desired products in high yield. Both primers (forward and reverse) possibly designed with the same melting temperature. Primer annealing temperature depends on its melting temperature value that is calculated as Melting temperature $(\mathrm{o} \mathrm{C})=4(\mathrm{G}+\mathrm{C})+2(\mathrm{~A}+\mathrm{T})$, where $\mathrm{A}, \mathrm{T}, \mathrm{G}$ and $\mathrm{C}$ stand for the number of corresponding nucleotides in the primer (Bhat and Rao, 2020).

Deoxynucleoside triphosphates (dNTPs): Nucleotides are mandatory for the extension of the newly synthesized DNA strand. The four nucleotides (dATP, dCTP, dGTP, dTTP) are included in the mixture.

Enzyme (Thermostable DNA polymerase): A the thermo-stable enzyme (Taq polymerase) is essential for polymerization as a result of that the polymerase reaction undertakes denaturation of the template at high temperature.

PCR buffer (10x): a buffer solution provided that a suitable chemical situation for ideal activity and stability of the DNA polymerase. A $10 \mathrm{mM}$ Tris- $\mathrm{HCl}$ buffer at a $\mathrm{pH}$ between 8.3 and 8.8 is needed for normal PCR (Bhat and Rao, 2020).

Divalent cation $\left(\mathbf{M g C l}_{2}\right)$ : All of the thermostable DNA polymerases need free divalent cations such as $\mathrm{Mg}^{+2}$ for activity. The concentration of $\mathrm{Mg}^{+2}$ needed for optimal reaction require to be determined for each of the primers and template. Generally, depends on primers and template the concentration of $\mathrm{Mg}^{+2}$ vary from 1.5 to $4.5 \mathrm{mM}$. (Bhat and Rao, 2020).

Reverse transcriptase: is used for the amplification of RNA, which mean RNA first converted to cDNA by the enzyme reverse transcriptase.

\subsubsection{Steps of polymerase chain reaction}

To carry out PCR, an extracted sample containing target DNA template is added to a tube holding primers, free nucleotides (dNTPs), and Taq polymerase. Subsequently the addition of all the components in a PCR tube, and then is placed in a PCR machine. The PCR machine increases and lowers the temperature within a certain time of the PCR mixture in automatic, programmed steps that create copies of the target sequence exponentially. Amplification occurs in three main steps:

Denaturation (strand separation): denaturation is the initial cycling and consisting of heating the reaction chamber at high temperature (commonly $3-5 \min$ at $90^{\circ} \mathrm{C}$ to $95^{\circ} \mathrm{C}$ ). The temperature is raised up to isolated double stranded DNA into two single-stranded DNA. This result melting of the double-stranded DNA (dsDNA) by breaking the hydrogen bonds between complementary bases to separate into two single-stranded DNA molecules. Annealing (primer binding): the reaction temperature is lowered to $40^{\circ} \mathrm{C}$ to $60^{\circ} \mathrm{C}$ for $20-40$ seconds to allow the binding of the primers to each of the single-stranded DNA templates at this stage. Two dissimilar primers are usually comprised in the reaction mixture: one for each of the two single-stranded DNA complements containing the target region.

Extension/elongation (synthesis of new DNA): In this stage, the temperature is raised $\left(68-75^{\circ} \mathrm{C}\right)$ and the DNA polymerase synthesizes a new DNA strand complementary to the target DNA by addition of free dNTPs from the reaction mixture that is complementary to the template in the $5^{\prime}$-to- $3^{\prime}$ direction, condensing the $5^{\prime}$-phosphate group of the dNTPs with the 3'-hydroxy group at the end of the nascent (elongating) DNA strand. The temperature at the extension step depends on the DNA polymerase used. The optimum activity temperature for the thermostable DNA polymerase of Taq polymerase is about $75-80{ }^{\circ} \mathrm{C}$ (Chien et al., 1976; Lawyer et al., 1993; Auwal, 2014) though a temperature of $72{ }^{\circ} \mathrm{C}$ is commonly used with Taq polymerase.

The processes of denaturation, annealing and elongation represent a single cycle. These steps are repeated for 20 to 40 cycles to amplify the DNA target to millions of copies. The newly made DNA segments used as a template in the next cycles (Mullis and Faloona, 1987; Rubio et al., 2020). The diagrammatic illustration of PCR is provided in Figure 1. 


\section{Polymerase chain reaction - PCR}

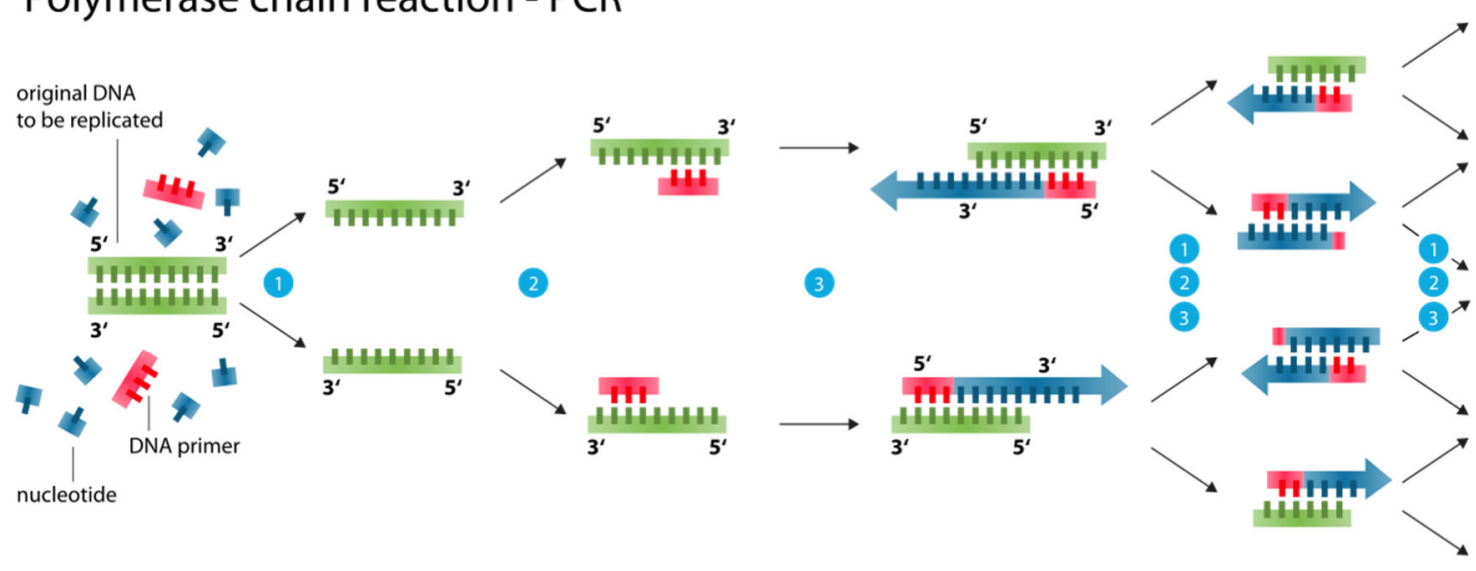

1 Denaturation at $94-96^{\circ} \mathrm{C}$

(2) Annealing at $\sim 68^{\circ} \mathrm{C}$

3 Elongation at $\mathrm{ca} .72{ }^{\circ} \mathrm{C}$

Figure 1. The diagrammatic representation of PCR. Source: https://en.wikipedia.org/wiki/Polymerase_chain_reaction

During each cycle, the sequence between the primers is doubled (Figure 2). The formula helped to determine the number of DNA copies created after a prearranged number of cycles is $2^{\mathrm{n}}, \mathrm{n}$ is number of cycles. Thus, a reaction set for 30 cycles results in $2^{30}$ copies of the original double-stranded DNA target region (Krawetz, 1989; Jackie Hughes et al., 2004).

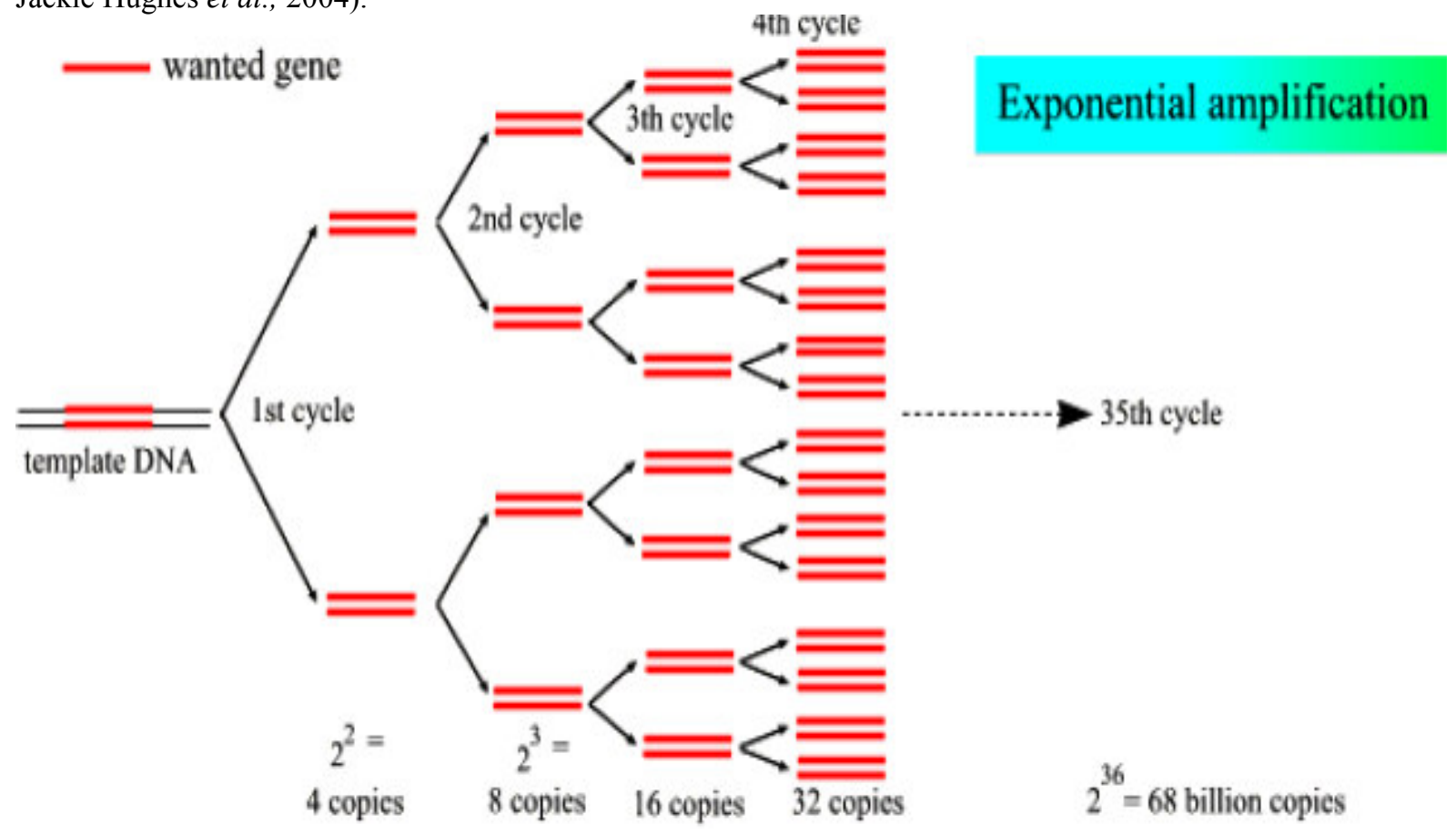

Figure 2. The diagrammatic representation of PCR cycle and exponential amplification. Source: https://users.ugent.be/ avierstr/principles/pcr.html

The results of the PCR product are visualized by agarose gel electrophoresis (Figure 3) and the bands are visualized by staining with ethidium bromide and irradiation with ultraviolet light (Sastry, 2013). The PCR product also can be more characterized by Sanger sequencing, allowing further precise identification by comparison with known sequences from databases like GenBank (Sastry et al., 2013; Rubio et al., 2020). 


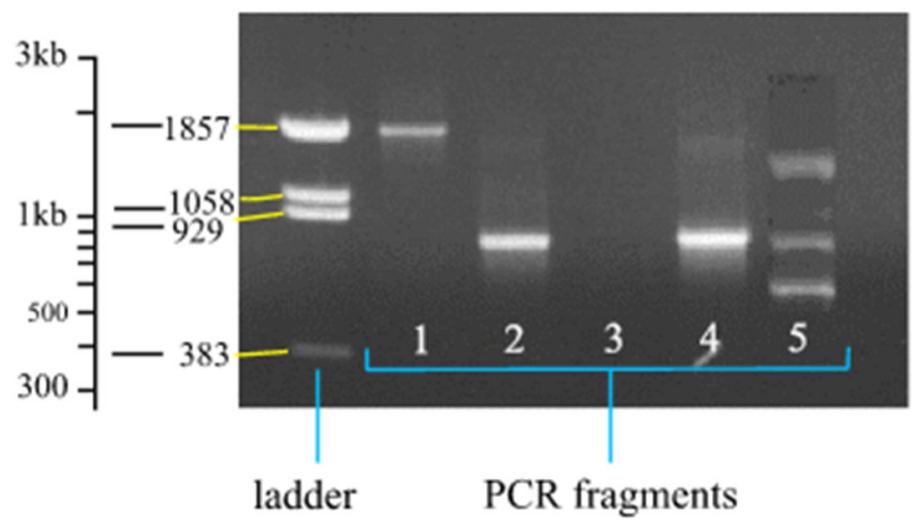

Fig 4. Verification of the PCR product on agarose gel electrophoresis. The ladder is a composite of fragments of known sizes to compare with the PCR fragments. Lane 1: PCR fragment is about 1850 bases long. Lane 2 and 4 about 800 bases long. Lane 3: no product is formed, so the PCR failed. Lane 5: multiple bands are formed for the reason that one of the primers fits in different areas. Source: https://users.ugent.be/ avierstr/principles/pcr.html

\subsubsection{Most common used types/variants of PCR}

There are numerous variations of PCR methods have been developed to improve its effectiveness method in diagnosis. Reverse Transcriptase PCR, Immunocapture PCR, Multiplex PCR, Co-operational PCR and Real-time PCR are among the variants PCR commonly used for plant virus detection.

\section{Reverse Transcriptase PCR (RT-PCR)}

The universal PCR technique is applicable directly to DNA plant viruses (Hema and Konakalla, 2021); it is not directly applicable to most plant viruses that have RNA genomes. About $70 \%$ of identified plant viruses have RNA genome which is single-stranded (ssRNA) (Bhat and Rao, 2020). For the detection of ssRNA viruses, RTPCR is a stranded method, which involves the first step of reverse transcription that converts single strand RNA to a complementary DNA (cDNA) copy with the aid of the enzyme reverse transcriptase before the starting of PCR (Sastry, 2013; Bhat and Rao, 2020). The resulting cDNA provides an appropriate DNA target for the next amplification where initial cycles of PCR, a complementary strand of DNA will be synthesized from the cDNA template followed by the generation of ds-DNA (Dellaporta et al., 1983; Jackie Hughes et al., 2004). Different RT-PCR variants have been developed, such as immune-capture RT-PCR, which has been used with plant extracts (Olmos et al., 2002) or with immobilized targets on paper print RT-PCR (Olmos et al., 1996).

Although the benefits of RT-PCR may outweigh its disadvantages, great care should be taken when performing a PCR reaction, for the reason that its good sensitivity and tremendous amplification potential, avoid false positives because of cross-contamination (Kwok and Higuchi, 1989; Candresse et al., 1998).

\section{Immunocapture (IC-PCR)}

IC-PCR was advanced for the detection and identification of different viral disease in plants (Wetzel et al., 1992; Nolasco et al., 1993) and is advantages for viruses with low concentration in the plant or for plant viruses their genome integrated into host plant genome (Dellaporta et al., 1983; Jackie Hughes et al., 2004). In this method, the virus particles are primary "concentrated" by trapping onto a solid surface (micro centrifuge tube or ELISA plate) by using virus-specific antibodies. The particles of the trapped virus are disrupted and the viral nucleic acid released is amplified by RT-PCR. This results in better sensitivity and the problems phased with RNA extraction are actuality minimized and RT-PCR inhibitors being washed away before amplification. Therefore, IC-PCR is the most important alternative for RT-PCR in detection of plant virus from diffident plant materials (leaf, stem, root and seed) and insect vectors (Latvala et al., 1997; James et al., 1997; Mumford and Seal, 1997; Jain et al., 1998; Candresse et al., 1998).

\section{Multiplex PCR}

More than one targets DNA or RNA can be detected all at once via multiplex PCR in a single reaction (Webster et al., 2004; Lopez et al., 2008). The technique required numerous specific primers to detect over two viruses at the same time (James et al., 2006; Li et al., 2011; Qu et al., 2011), and thus a single test run is used instead of specific test runs for each virus. This saves on reagents and time. The annealing temperatures for each of the primer sets should be optimized to perform properly within a single reaction and amplicon sizes, i.e., their base-pair length, could be different form distinct bands when visualized by gel electrophoresis (Hull, 2014).

Regardless of this advantage, conventional PCR is used more than multiplex PCR, as a result of the procedural complexity of reaction mixture involving multiple compatible primers (Lopez et al., 2008). Furthermore, it is difficult to design specific primer for each target DNA and to differentiate with the difference DNA amplification of each size of the gene (Webster et al., 2004; Lopez et al., 2008). 


\section{Co-operational PCR (Co-PCR)}

Recently a new highly sensitive PCR concept has been described for the amplification of viral RNA targets from plant material (Roger and Norwitch, 2009). The Co-PCR method has been patented as a co-operational amplification method which possibly accomplished easily in a simple reaction based on the simultaneous action of four or three primers.

A major difficulty to the use of conventional PCR is the presence of PCR inhibitors. The problem can be overwhelmed by Co-PCR with diluted samples. Undiluted samples show a weak product by co-PCR while diluted samples provide a well signal (Caruso et al., 2003; Capote et al., 2009). According to the Cherry leafroll virus detection, the co-PCR sensitivity observed in virus detection is at least 100 times higher than RT-PCR (Olmos et al., 2002).

\section{Real-time PCR}

The innovative real-time quantitative PCR test (TaqMan technology) was developed for the detection and quantification of plant viruses (Mumford et al., 2000; Roberts et al., 2000; Ruiz-Ruiz et al., 2009). Furthermore, the sensitivity and specificity of real-time PCR, the method has some advantages over RT-PCR; reduces the risk of cross-contamination, eliminates post PCR manipulations, offers higher performance, and allows the quantification of virus load to a given sample. But the real-time PCR technique requires more expensive and special apparatus and reagents compared to conventional PCR. Detection and identification using real-time PCR is not only detecting the presence or absence of the target pathogen but also measuring the amount present in a sample that allows the quantitative measure of the virus pathogen in the sample (Sastry, 2013).

Real-time PCR can be considerably reduced detection time and can be used for a small concentration of target genetic material making it possible to diagnose (Lopez et al., 2008; Heid et al., 2011) because of no need for the gel electrophoresis for the confirmation.

\section{CONCLUSIONS}

Plant virus diseases result in the loss of production and productivity by limiting plant production quantity and quality in the world. Proper diagnosis is the most important tool for the development of effective plant virus disease management. The development of nucleic acid-based detection and identification of plant viruses was a new dimension. the polymerase chain reaction is the most advanced and commonly used among nucleic acid-based methods. Currently, PCR is a popular method of diagnosing plant viruses in a laboratory and is widely used in molecular testing. PCR is able to process by the specificity of the primers. A standard PCR has performed in three steps:(i) denaturation (DNA strand separation at high temperature), (ii) annealing of primers, and (iii) primer extension/elongation. Several variations of PCR methods are designed to improve the use of the method in diagnostic settings based on their applications.

\section{REFERENCES}

Agrios, G. N. 2005. Plant Pathology. $5^{\text {th }}$ eddition. Elsevier Academic Press, 952.

Alfaro-Fernandez, A., Cebrian, M. C., Cordoba-Selles, C., Herrera-Vasquez, J. A. and Jorda, C. 2008. First report of the US1 strain of Pepino mosaic virus in tomato in the Canary Islands, Spain. Plant Dis. 92:1590-1590.

Auwal, I. 2014. Nucleic Acid Amplification as used in the Diagnosis and Management of Viral Diseases: A Review. Bayero Journal of Pure and Applied Sciences, 7(1): p. 24-33.

Bhardwaj, A. and Kulshrestha, S. 2020. Advance methods for the isolation and characterization of plant viruses infecting crops. Applied Plant Virology, 39-53. doi:10.1016/b978-0-12

Bhat A. I., Rao G. P. (2020). Rolling circle amplification (RCA), in Characterization of Plant Viruses - Methods and Protocols (Humana, New York: Springer;), 377-382.

Candresse, T. R., Hammond, and Hadidi, A. 1998. Detection and identification of plant viruses and viroids using polymerase chain reaction (PCR). Pages 399-416 in Control of plant virus diseases, edited by A. Hadidi, R.K. Khetarpal, and K. Koganezawa. APS Press, St. Paul, MN, USA.

Capote, N., Bertolini, E., Olmos, A., Vidal, E., Martinez, M. C. and Cambra, M. 2009. Direct sample preparation methods for the detection of Plum pox virus by real-time RT-PCR. Int. Microbiol. J. 12: 1-6.

Chien, A., Edgar, D. B. and Trela, J. M. 1976. Deoxyribonucleic acid polymerase from the extreme thermophile Thermus aquaticus. J. Bacteriol. 127 (3): 1550-1557. doi:10.1128/jb.127.3.1550-1557.1976.

Davis, R. I. and Ruabete, T. K. 2010. Records of plant pathogenic viruses and virus-like agents from 22 Pacific island countries and territories: a review and an update. Australasian Plant Pathology 39: 265-291.

Dellaporta S.L., Wood J. and Hicks J.B. 1983. A plant DNA mini-preparation Version II. Plant Molecular Biology Reporter 1: 19-21

Elena, S. F., Fraile, A. and Garciá -Arenal, F. 2014. Evolution and emergence of plant viruses. Adv. Virus Res. 88, 161-191. doi: 10.1016/B978-0-12-800098-4.00003-9

Heid, C. A., Stevens, J., Livak, K. J. and Williams, M. P. 2011. Real time quantitative PCR. Genome Res. 6: 986994 
Hema, M. and Konakalla, N.C. 2021. Recent developments in detection and diagnosis of plant viruses, Elsevier BV. https://doi.org/10.1016/B978-0-12-821406-0.00016-3

Henson, J. M. and French, R. 1993. The polymerase chain reaction and plant disease diagnosis. Annual Review of Phytopathology 31: 81-109.

Hull, R. 2014. Assay, Detection, and Diagnosis of Plant Viruses. Plant Virology, 755-808. doi:10.1016/b978-012-384871-0.00013-3

Jackie Hughes, Sam Offei, Blake Rollenfitch. 2004. Plant viruses in Sub-Saharan Africa. A Practical Laboratory Manual. International Institute of Tropical Agriculture, Ibadan, Nigeria.

Jain, R.K., Pappu, S.S., Pappu, H.R., Culbreath, A.K. and Todd, J.W. 1998. Molecular diagnosis of tomato spotted wilt tospovirus infection of peanut and other fi eld and greenhouse crops. Plant Disease 82: 900-904.

James, D., Trytten, P. A., Mackenzie, D. J., Towers, G. H. N. and French, C. J. 1997. Elimination of apple stem grooving virus by chemotherapy and development of an immunocapture RT-PCR for rapid sensitive screening. Annals of Applied Biology 131: 459-470.

Jones, R. A. C. 2009. Plant virus emergence and evolution: origins, new encounter scenarios, factors driving emergence, effects of changing world conditions, and prospects for control. Virus Res. 141, 113-130. doi: $10.1016 / \mathrm{j}$. virusres.2008.07.028

Kiss, L., Sebestyén, E., László, E., Salamon, P., Balázs, E., and Salánki, K. 2008. Nucleotide sequence analysis of Peanut stunt virus Rp strain suggests the role of homologous recombination in cucumovirus evolution. Arch. Virol. 153:1373- 1377.

Koenig, R., Lesemann, D. E., Adam, G., Winter, S. 2008. "Diagnostic Techniques: Plant Viruses", Elsevier BV.

Krawetz, S. A. 1989. The polymerase chain reaction: opportunities for agriculture. Ag. Biotech. News and Information 1: 897-901.

Kwok, S. and Higuchi, R. 1989. Avoiding false positives with PCR. Nature 339: 237-238.

Lange, L. and Heide, M. 1986. Dot immuno binding (DIB) for detection of virus in seed. Canadian Journal of Plant Pathology 8: 373-379.

Lankow, R. K., Grothaus, G. D. and Miller, S. A. 1987. Immunoassays for crop management systems and agricultural chemistry. In: Biotechnology in Agricultural Chemistry, ACS Symposium series. H.M. LeBaron, R.O. Mumma, R.C. Honeycutt, J.H. Duesing (eds.). Washington D.C. American Chemical Society, 334: 228252.

Latvala, S., P. Susi, A. Lemmetty, S. Cox, A. T. Jones, and K. Lehto. 1997. Ribes host range and erratic distribution with in plants of blackcurrant reversion associated virus provide further evidence for its role as the causal agent of reversion disease. Annals of Applied Biology 131: 283-295.

Lawyer, F., Stoffel, S., Saiki, R., Chang, S., Landre, P., Abramson, R., Gelfand, D. 1993. High-level expression, purification, and enzymatic characterization of full-length Thermus aquaticus DNA polymerase and a truncated form deficient in 5' to 3' exonuclease activity. PCR Methods and Applications. 2 (4): 275287. doi:10.1101/gr.2.4.275.

Li, M., Asano, T., Suga, H. and Kageyama, K. 2011. A multiplex PCR for the detection of Phytophthora nicotianae and P. cactorum, and a survey of their occurrence in strawberry production areas of Japan. Plant Dis. 95: $1270-1278$.

Lopez, M. M., Llop, P., Olmos, A., Marco-Noales, E., Cambra, M. and Bertolini, E. 2008. Are molecular tools solving the challenges posed by detection of plant pathogenic bacteria and viruses? Curr. Issues Mol. Biol. 11: $13-45$.

Makkouk, K. M. and Kumari, S. G. 2006. Molecular Diagnosis of Plant Viruses. Arab J. Pl. Prot.

Menzel, W., Jelkmann, W. and Maiss, E. 2002. Detection of four apple viruses by multiplex RT-PCR assays with coamplification of plant mRNA as internal control. J. Virol. Methods 99: 81-92.

Mullis, K.B., Faloona, F., Scharf, S., Saiki, R., Horn, G. and Erlich, H. 1986. Specific enzymatic amplification of DNA in vitro: the polymerase chain reaction. Cold Spring Harb. Symp. Quant. Biol. 51, 263-273. 52

Mumford, R., Macarthur, R. and Boonham, N. 2016. The role and challenges of new diagnostic technology in plant biosecurity. Food Secur. 8, 103-109. doi: 10.1007/s12571-015-0533-y

Mumford, R. A. and Seal, S. E. 1997. Rapid single-tube immunocapture RT-PCR for the detection of two yam potyviruses. Journal of Virological Methods 69: 73-79.

Mumford, R. A., Walsh, K., Barker, I. and Boonham, N. 2000. Detection of potato mop top virus and tobacco rattle virus using a multiplex real-time fl uorescent reverse-transcription polymerase chain reaction assay. Phytopathology 90: 448-453.

Nolasco, G., de Blas, C. Torres, V. and Ponz, F. 1993. A method combining immunocapture and PCR amplifi cation in a microtitre plate for the detection of plant viruses and subviral pathogens. Journal of Virological Methods 45: 201-218.

Olmos, A., Bertolini, E., Cambra, M. 2002. Simultaneous and co-operational amplification (Co-PCR): a new concept for detection of plant viruses. Journal of Virological Methods., 106 (1):51-59. 
Pantaleo, V., Saponari, M. and Gallitelli, D. 2001 Development of a nested PCR protocol for detection of oliveinfecting viruses in crude extracts. J. Plant Pathol. 83: 143-146

Qu, X. S., Wanner, L. A. and Christ, B. J. 2011. Multiplex real-time PCR (TaqMan) assay for the simultaneous detection and discrimination of potato powdery and common scab diseases and pathogens. J. Appl. Microbiol. 110: 769-777.

Regassa B, Abraham A, Fininsa C, Wegary D, Wolde-Hawariat Y (2020) Distribution of maize lethal necrosis epidemics and its association with cropping systems and cultural practices in Ethiopia. Crop Protection, 134, 105151. doi: 10.1016/j.cropro.2020.105151.

Regassa B, Abraham A, Fininsa C, Wegary D. Alternate hosts and seed transmission of maize lethal necrosis in Ethiopia. J Phytopathol. 2021; 00:1-13. https://doi.org/10.1111/jph.1298.

Roberts, C.A., Dietzgen, R. A., Heelan, L.A. and Maclean, D. J. 2000. Real-time RT-PCR fluorescent detection of tomato spotted wilt virus. Journal of Virological Methods 88:1-8.

Roger, H., Norwitch. (2009). Comparative plant virology, second edition, Elsevier academic press.

Roossinck, J. 2002. Evolutionary history of Cucumber mosaic virus deduced by phylogenetic analysis. J. Virol. 76:3382-3387.

Rubio L, Galipienso, L. and Ferriol, I. 2020. Detection of Plant Viruses and Disease Management: Relevance of Genetic Diversity and Evolution. Front. Plant Sci. 11:1092. doi: 10.3389/fpls.2020.01092

Ruiz-Ruiz, S., Ambros, S., del Carmen Vives, M., Navarro, L., Moreno, P. and Jose, G. 2009. Detection and quantitation of Citrus leaf blotch virus by TaqMan real-time RT-PCR. J. Virol. Methods 160: 57-62.

Sastry, K. S. 2013. "Plant Virus and Viroid Diseases in the Tropics", Springer Science and Business Media LLC.

Varma, A. and Singh, M. K. 2020. Diagnosis of plant virus diseases. Applied Plant Virology, 79-92.

Vincelli, P., and Tisserat, N. 2008. Nucleic acid-based pathogen detection in Applied Plant Pathology. Plant Dis. $92: 660-669$.

Webster, C. G., Wylie, J. S. and Jones, M. G. K. 2004. Diagnosis of plant viral pathogens. Curr. Sci. 86: 16041607.

Wetzel, T., Candresse, T., Macquaire, G., Ravelonandro, M. and Dunez, J. 1992. A highly sensitive immunocapture polymerase chain reaction method for plum pox potyvirus detection. Journal of Virological Methods., 39:27-37.

Wetzel, T., Candresse, T., Macquaire, G. Ravelonandro, M. and Dunez, J. 1992. A highly sensitive immunocapture polymerase chain reaction method for plum pox potyvirus detection. Journal of Virological Methods 39: 2737. 